\title{
Tracing the J-Curve Effect in Halal and non-Halal Beverages Industry in Malaysia
}

\author{
Dhakir Abbas Ali ${ }^{1}$, Fuadah Johari ${ }^{1} \&$ Mohammad Haji Alias ${ }^{1}$ \\ ${ }^{1}$ Faculty of Economics and Muamalat, Universiti Sains Islam Malaysia (USIM), Nilai, Negeri Sembilan, \\ Malaysia \\ Correspondence: Fuadah Johari, Faculty of Economics and Muamalat, Universiti Sains Islam Malaysia (USIM), \\ 71800 Nilai, Negeri Sembilan, Malaysia. E-mail: fuadah@usim.edu.my
}

Received: April 25, 2014 Accepted: May 19, 2014 Online Published: June 25, 2014

doi:10.5539/ass.v10n13p222 URL: http://dx.doi.org/10.5539/ass.v10n13p222

\begin{abstract}
Some studies have tried recently to assess the causes of Malaysia's substantially increasing trade in non-Halal beverages. However, no study assessed the dynamic effects of real exchange rate movements, known as the J-Curve theory. To have a comparative basis for the analysis, we assess the theory in both Halal and non-Halal beverages between Malaysia and five of its largest trading partners independently for the period 1994-2012. Using ARDL approach to cointegration, and ECM model we find that: (1) Malaysia's trade in beverages in the short-run is affected by exchange rate movements in most of the cases, (2) Most importantly, Malaysia's trade in non-Halal beverages seems not to be affected by none of the economic explanatory variables used in the study in the long-run, and (3) Among the ten cases of five partners and two sectors, we find support for the J-Curve in the case of bilateral trade with the UK in Halal beverages.
\end{abstract}

Keywords: exchange rate, Halal and non-Halal beverages, J-Curve theory, trade balance

\section{Introduction}

The term Halal, as originally used in Arabic, refers to all what is permitted in Islam, whereas Haram is what Islam forbids (Baalbaki \& Ba'albaki, 1999). In Islam, Halal refers to permissible behavior, communication, clothing, demeanor, dietary, etc. The Halal-Haram dichotomy applies to almost every aspect of Muslims' life, Muslims make sure they grasp what is what since being compliant with Sharia (Halal doing) leads to paradise, while incompliance with Sharia (Haram doing) leads to hell (Al-Qardawi, 1997). For non-Muslims, however, Halal is mainly used in reference to merely food and beverages compliant with Sharia (Al Jallad, 2008).

Examples of Haram in diet include any food derived from pork i.e. ham, gammon, bacon, pork-based products. Additionally, animals slaughtered in ways other than the taught in Islam, and intoxicants (Regenstein, Chaudry, \& Regenstein, 2003).

Intoxicants in Islam mainly include any alcoholic beverages (Khamr) which leads to intoxication. However, it should be noted that the prohibition of intoxicants in Islam came gradually not to make it hard for Muslims to quit (Michalak \& Trocki, 2006). First, Allah described to Muslims that the harm of drinking alcoholic beverages is greater than the benefit; next, He told them not to pray while intoxicated; and finally, He revealed the verse which prohibited it completely and conclusively: "O you who believe! Truly, intoxicants and gambling and divination by arrows are an abomination of Satan's doing: avoid it in order that you may be successful" Surah al-Maidah, verse 90.

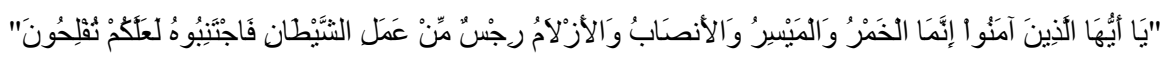

As agreed by almost all Muslim scholars, Allah strictly prohibited toxicants, describing them as abominable or filthy (Rijs), a term which Qur'an reserves for describing tremendously indecent behavior (Al-Qardawi, 1997).

Talking about the prohibition of intoxicants in Islam, many guidelines related to this rule could be summarized as follows:

- All what intoxicates is Haram, not necessarily alcoholic beverages: The Prophet, peace be on him, has said "Every intoxicant is khamr, and every khamr is haram." reported by Muslim (Wan Hassan \& Awang, 2009); 
- Whatever intoxicates in large amounts is Haram in any amount: Allah's Prophet said, "Of that which intoxicates in a large amount, a small amount is haram." reported by Ahmad Abu Daoud, and al-Tirmidhi (Sabry \& Vohra, 2013); and,

- Islam blocks all the avenues leading to Haram: For the case of toxicants, prophet Muhammad, peace be upon him, said "Truly, Allah has cursed khamr and has cursed the one who produces it, the one for whom it is produced, the one who drinks it, the one who serves it, the one who carries it, the one for whom it is carried, the one who sells it, the one who earns from the sale of it, the one who buys it, and the one for whom it is boughts" reported by al-Tirmidhi and Ibn Majah, on reliable authority (Michalak \& Trocki, 2006). As stated by the high profile Muslim scholar Yusuf Al-Qardawi, and agreed by many other scholars, "Allah also forbade any trading in it, even with non-Muslims. It is not permissible for a Muslim to import or export alcoholic beverages, or to own or work in a place which sells them" (Al-Qardawi, 1997).

As this study is concerned about the case of Malaysia as a majority-Muslim country (Nasr, 2005), we open the discussion by reviewing trade data for the period 1994-2012. Figure 1 depicts Malaysia's merchandise in beverages, both Halal and non-Halal, with five of its major trade partners i.e. China, Singapore, Japan, the US and UK. Each trade flow shown in the figure represents the overall value of trade with the five trade partners accumulatively. The values are in millions of dollars and the data is all reported by Malaysia to the United Nations Comtrade program.

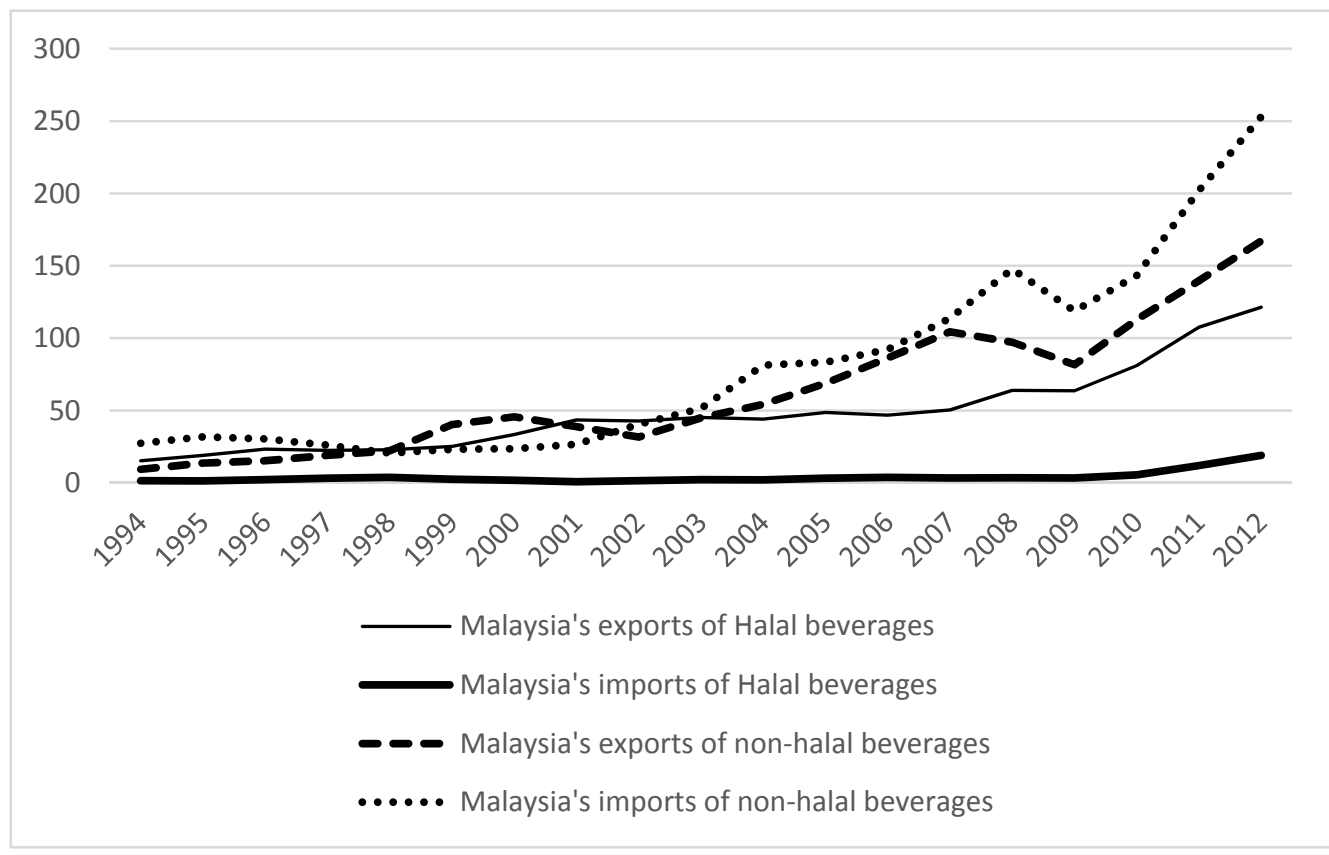

Figure 1. Malaysia's merchandise in beverages (Source: United Nations Commodity trade, retrieved from the Standard International Trade Classification revision 1)

By looking at the previous figure 1, we could see a clear upward trend in the trade of non-Halal beverages in Malaysia, what explains this increase? Searching for answers to this question could be better examined by first taking a look on the demographics of Malaysia.

Malaysia is a multiethnic country, in which the main ethnic groups, namely the Malays, Chinese and Indians, live harmoniously (Rashid \& Ho, 2003). Today, the Malays account for nearly $60 \%$ of the total population, of whom the black majority are Muslims, while the Chinese accumulate 30\% and Indians nearly 10\% (Ngow et al., 2009). As such, Malaysia has a diverse cultural beliefs and values. Thus, the high level of merchandise in non-Halal beverages could be understood since not necessarily the Muslims are the ones who are consuming. However, this diversity in religion still cannot explain the substantial rise in trade since the races are still in the same balance during the 19 years depicted in figure 1. 
Some researchers have investigated the role of ethnicity in the consumption of alcoholic beverages in Malaysia (Jernigan \& Indran, 1997; Kortteinen, 1999; Ngow et al., 2009; Tan, Yen, \& Nayga Jr, 2009), where some other studies examined the role of tourism (Henderson, 2003; Russell, 2003).

However, this study examines for the first time, the role of real exchange rate. This study particularly ivstigates what is called the J-Curve theory. To assess the effect comparatively, the study investigates the same effects in both Halal and non-Halal beverages with each of Malaysia's major trade partners.

The study is organized as follows, the second section explains the J-Curve theory. Section [3] states the empirical model and the data used for the analysis, while Section [4] summarizes the results. The final Section concludes the study by a concise summary.

\section{The J-Curve theory}

The logical basis of the J-Curve theory comes from the Marshall-Lerner Condition, which in its turn is nothing but a special case of the wider elasticities approach. The Condition states that; in order for currency depreciation to have a favorable impact on trade balance, the sum of the absolute demand elasticities of export and import has to mount at least one (Auboin \& Ruta, 2013).

In all theories which discussed the effect of real exchange rate depreciation on trade balance under the guidelines of the elasticities approach, including the J-Curve theory, changes in exchange rate have basically two effects on trade balance. The effects are distinguished to be the value and volume effects. According to the J-Curve, devaluation in domestic currency increases the relative prices of imports in terms of domestic currency. Simultaneously, it decreases the price of domestic exports as paid in foreign currency. In other words, exports become cheaper for foreign importers and imports become more expensive for domestic importers. The two effects combined together are called the value effect. Given the value effect, currency depreciation starts to cause the traded amounts of exports to increase and the imported amounts to decrease, the two effects combined together are called the volume effect (Anju \& Uma, 1999).

If volume effect is greater than value effect, the Marshall-Lerner condition is met. However, usually in the short-run, the Marshall-Lerner condition is not met since the adjustment of volume tends to be inelastic in the short-run, thus, depreciation forces trade balance to deteriorate initially as an instant value effect reaction to currency depreciation (Magee, 1973).

In the long run, traders adjust the volume of their trade in line with the new prices; hence, the volume effect is generally believed to exceed the price effect causing trade balance to improve. The combination of the short-run deterioration and long run improvement of trade balance as a results of currency depreciation is similar to the English letter J. The J-curve phenomena was first observed by Magee (1973) as can be seen in Figure 2.

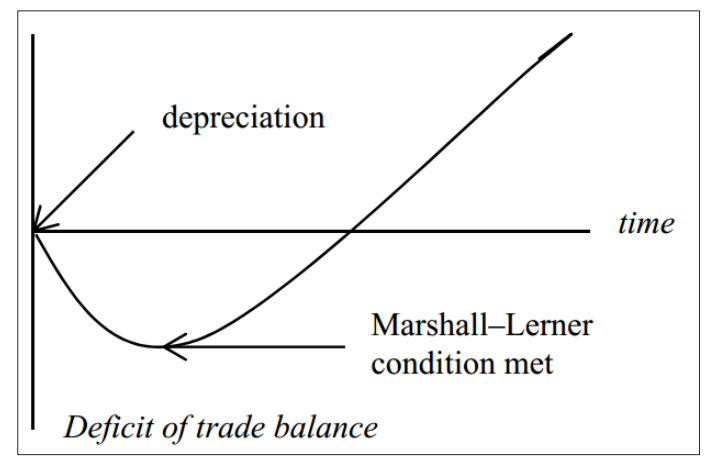

Figure 2. J-curve phenomena (Source: Clarke \& Kulkarni, 2010)

Junz \& Rhomberg, (1973) attribute the J-like adjustment path of trade balance as a reaction to exchange rate depreciation to five types of lags: the recognition of exchange rate changes, the decision to change real variables, delivery time, the replacement of inventories and materials, and the production.

Krueger, (1983) explains the J-Curve phenomena by asserting the fact that once exchange rate depreciation happens, goods already in transit or under contracts signed before the changes in price prevail in the short-run, which hinders the volumes effect from work and causes trade balance to deteriorate, but since the demand for 
exports and imports is elastic in the long-run more than the short-run, the volume effect gets to work, causing trade balance improvement.

However, the reason why we investigate the J-Curve theory in the trade of beverages in Malaysia is only because of its dynamicity. Thus, it allows us to differentiate between the short-run and long-run effects of exchange rate depreciation on the trade balance of beverages.

\section{The Model and Data}

In testing the J-Curve theory, it is a common practice to rely on the reduced-form model of trade balance, in which a measure of the trade balance depends on the level of economic activity in both trade partners besides the real bilateral exchange rate. Thus, we adopt the trade balance (TB) model suggested by Bahmani-Oskooee and Wang (2008) which takes the following long-run reduced form:

$$
\ln T B_{i, t}=\alpha+\beta \ln Y_{M a, t}+\gamma \ln Y_{x, t}+\varphi \ln R E X_{i, t}+\mu_{t}
$$

Where $\mathrm{i}$ indicates the investigated sector (Halal or non-Halal with a specific partner). Since sector level data are reported by Malaysia, we formulate the trade balance from the Malaysian perspective. Thus, TB is defined as the ratio of Malaysia's imports of sector i from country $x$ over its exports of the same industry from the same partner. Thus, an increase in TB indicates sectoral trade balance deficit for Malaysia. Furthermore $\mathrm{i}=10$, since we investigate Halal and non-Halal beverages trade of Malaysia with five of its major trading partners $(x=5)$. The measure of the trade balance as a ratio makes it unit-free, which enables us to specify the model in log form to interpret the results in terms of percent change and reduce the variance of the variables.

Theoretically, TB is expected to depend positively on a measure of Malaysia's real GDP $\left(Y_{M a}\right)$, and negatively on a measure of real GDP in country $\mathrm{x}\left(Y_{x}\right)$. Hence, $\beta$ is expected to be positive and $\gamma$ is expected to be negative.

As shown in Appendix A, the real bilateral exchange rate, REX, is defined in a way that an increase reflects a depreciation of the Malaysian Ringgit. Therefore, if a depreciation of the Ringgit is to improve trade balance, an estimate of $\varphi$ is expected to be negative.

Figure 3 shows how the real exchange rate behaved over the study period, measured in relation to Malaysia's major trade partners:

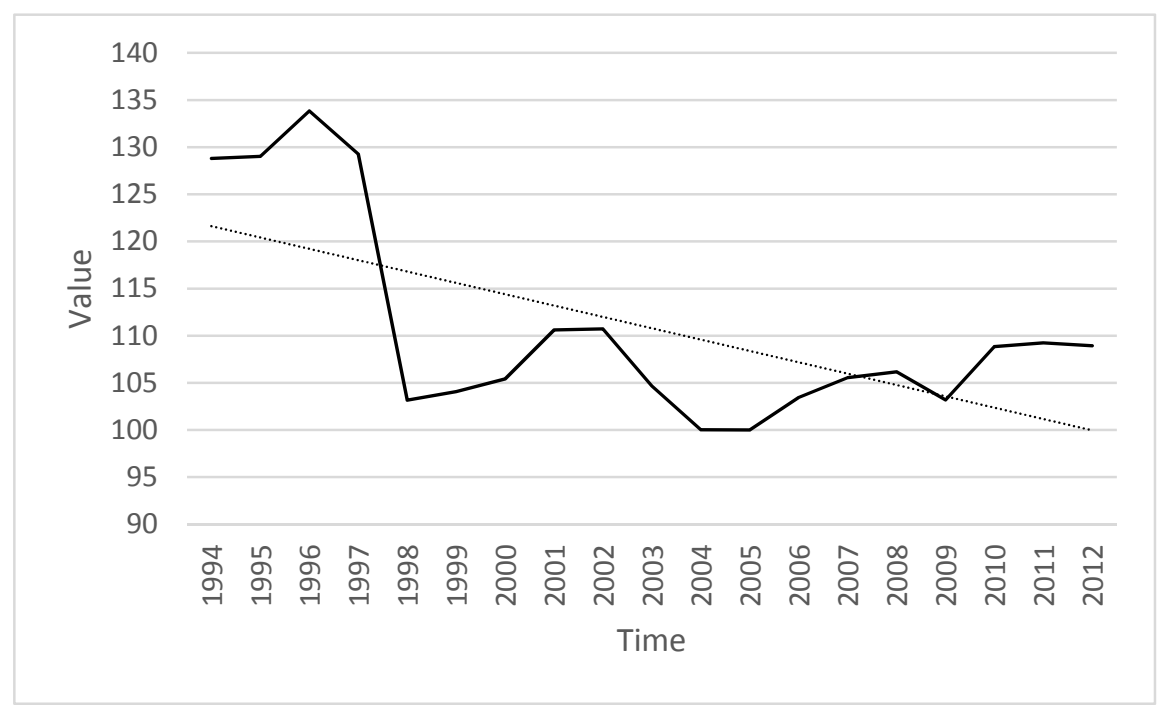

Figure 3. Real effective exchange rate of Ringgit (Source: International Financial Statistics of IMF-IFS $(\mathrm{CD}-\mathrm{ROM}))$

As Figure 3 clearly shows, a general trend of Ringgit appreciation against its major trade partners has prevailed during the period of the study. However, this general tendency cannot be simply generalized over all of Malaysia's trade partners separately. Thus, we include bilateral real exchange rate to investigate the J-Curve with each of Malaysia's partners as described in Appendix A. 
The reduced-form model stated in equation 1, is a long-run model, and coefficient estimates by any means are long-run estimates. Given that the J-Curve phenomenon is a dynamic theory, Equation [1] needs to be rewritten to include the short-run effects. An error-correction modeling technique provides all the necessary concepts to assess the short-run response of the trade balance to currency movements. Using such technique has an additional appealing purpose, in that, it yields long-run in addition to short-run effects. The error-correction specification adopted here follows the bounds testing technique of Pesaran, Shin, and Smith (2001), outlined in Equation 2:

$$
\begin{gathered}
\Delta L n T B_{i, t}=\alpha+\sum_{k=1}^{n_{1}} \emptyset_{k} \Delta \ln T B_{i, t-k}+\sum_{k=0}^{n_{2}} \beta_{k} \Delta \ln Y m a_{t-k}+\sum_{k=0}^{n_{3}} \gamma_{k} \Delta \ln Y x_{t-k}+\sum_{k=0}^{n_{4}} \varphi_{k} \Delta \ln R E X_{i, t-k}+ \\
\delta_{1} \ln T B_{i, t-1}+\delta_{2} \ln Y m a_{t-1}+\delta_{3} \ln Y x_{t-1}+\delta_{4} \ln R E X_{i, t-1}+\mu_{i}
\end{gathered}
$$

Equation 2 is an error-correction model that includes a linear combination of lagged level variables rather than the lagged error term from 1.

In this setup, cointegration is supported if the lagged level variables are jointly significant. Pesaran, Shin, and Smith (2001) propose applying the F-test with new critical values that account for stationarity of variables, and small-sample critical values were later computed by Narayan (2005). Through Monte Carlo experiments, by assuming all variables in a given model to be integrated of order one, they provide an upper-bound critical value that is sensitive to the number of variables. A lower-bound critical value is provided, for when all variables are stationary or integrated of order zero. If the variables are to be cointegrated, the calculated F statistic for the joint significance of the lagged level variables must be greater than the upper-bound critical value. Pesaran, Shin, and Smith (2001) then demonstrate that the critical values are still valid even if some variables are stationary and some nonstationary, ruling out pre-unit-root testing. Once Equation [2] is estimated, the long-run effects of real depreciation are inferred by the size and significance of $\delta_{4}$ normalized on $\delta_{1}$. The same normalization applies to other variables as well. The short-run J-curve effect is inferred by the sign and significance of estimated k's. Positive values for initial k's followed by negative values for subsequent k's will support the J-Curve. The error-correction model in 2 is subject to empirical analysis in the next section

\section{Empirical Results}

The study extends over a 19 year span (1994-2012). Using annual data, it assesses the J-Curve bilaterally in two sectors of Halal and non-Halal beverages in Malaysia with five of its largest trading partners (Singapore, China, Japan, US, and UK). The results are presented in three sections. Section [4.1] is for cointegration, while [4.2] and [4.3] are for short-run and long-run coefficient estimates, respectively. In each section, the results are presented first, and followed then by a summary.

\subsection{Cointegration among Variables}

Table 1. Cointegration results

\begin{tabular}{llcccc}
\hline $\begin{array}{l}\text { Data description } \\
\text { Sector } \\
\text { code }\end{array}$ & Description & $\begin{array}{c}\text { Cointegration results } \\
\text { Optimal } \\
\text { lag }\end{array}$ & $\begin{array}{c}\text { F-Test at } \\
\text { optimal lags }\end{array}$ & $\begin{array}{c}\text { Autocorrelation } \\
\text { LM test }\end{array}$ & ECT $_{\text {t-1 }}$ \\
\hline $\mathbf{1 1 1}$ & TB with Singapore in Halal beverages & 1.2 .1 .2 & 414.50 & 2.44 & $-3.44^{*}$ \\
$\mathbf{1 1 1}$ & TB with Japan in Halal beverages & 1.1 .0 .2 & 4.41 & 1.09 & $-1.11^{*}$ \\
$\mathbf{1 1 1}$ & TB with the US in Halal beverages & 1.2 .2 .2 & 4.46 & 2.05 & -0.38 \\
$\mathbf{1 1 1}$ & TB with the UK in Halal beverages & 1.2 .2 .2 & 24.53 & 0.93 & $-0.85^{*}$ \\
$\mathbf{1 1 1}$ & TB with the China in Halal beverages & 1.1 .2 .2 & 102.05 & 0.41 & $-1.60^{*}$ \\
$\mathbf{1 1 2}$ & TB with Singapore in non-Halal beverages & 1.2 .2 .2 & 150.65 & 6.80 & $-1.14^{*}$ \\
$\mathbf{1 1 2}$ & TB with Japan in non-Halal beverages & 1.2 .1 .2 & 16.45 & 1.99 & $-0.84^{*}$ \\
$\mathbf{1 1 2}$ & TB with the US in non-Halal beverages & 2.2 .1 .2 & 4.22 & 2.16 & $-0.52^{* *}$ \\
$\mathbf{1 1 2}$ & TB with the UK in non-Halal beverages & 1.1 .2 .1 & 4.62 & 0.06 & $-1.45^{*}$ \\
$\mathbf{1 1 2}$ & TB with the China in non-Halal beverages & 1.2 .2 .2 & 21.41 & 45.59 & -0.44 \\
\hline
\end{tabular}

* indicates significance at $5 \%$ level, ** indicates significance at $10 \%$ 
Probing cointegration as argued by Kremers, Ericsson, and Dolado (1992), a negative and significant $\mathrm{ECT}_{\mathrm{t}-1}$ can be seen in eight cases out of ten, supporting cointegration.

However, we find stronger support for cointegration following ARDL, we first apply two lags for all first differenced variables in equation [2], and then, we follow the General to Specific Approach suggested by Hendry and Mizon (1990) to get to the best specification. As tabulated by Narayan (2005), the upper bound critical value for small samples is $\mathrm{F}=4.15$ at $10 \%$ level of significance. Thus, cointegration could be supported for all ten regressions. All regressions are autocorrelation free.

\subsection{Short-run Coefficient Estimates of REX}

In order to save the space, this section presents the short-run coefficient estimates for the variable of interest only, the real exchange rate (REX) as shown in Table [2].

Table 2. Short-run effects of REX on trade balance

\begin{tabular}{|c|c|c|c|c|c|c|c|c|}
\hline \multicolumn{4}{|c|}{ REX Short-run estimates ${ }^{a}$} & \multicolumn{5}{|c|}{ Diagnostic tests ${ }^{b}$} \\
\hline Description & $\begin{array}{r}\Delta \mathrm{Ln} \\
\mathrm{REX}_{\mathrm{t}}\end{array}$ & $\begin{array}{c}\Delta \mathrm{Ln} \\
\operatorname{REX}_{\mathrm{t}-1}\end{array}$ & $\begin{array}{c}\Delta \mathrm{Ln} \\
\operatorname{REX}_{\mathrm{t}-2}\end{array}$ & $\begin{array}{l}\text { Adj. } \\
\mathrm{R}^{2}\end{array}$ & RESET & $\begin{array}{l}\text { LM } \\
\text { Test }\end{array}$ & $\begin{array}{l}\text { CUSUM } \\
\text { /CUSUM Q }\end{array}$ & $\begin{array}{l}\text { White } \\
\text { test }\end{array}$ \\
\hline TB with Singapore in & & 40.46 & & 0.86 & $(0.55)$ & $(0.61)$ & $\mathrm{S} / \mathrm{S}$ & $(0.22)$ \\
\hline Halal beverages & & $(7.6)^{*}$ & & & & & & \\
\hline TB with Japan in & & & 9.45 & 0.22 & $(4.57)^{* *}$ & $(0.76)$ & $\mathrm{S} / \mathrm{S}$ & $(1.56)$ \\
\hline Halal beverages & & & $(2.0)^{* *}$ & & & & & \\
\hline TB with the US in & & -4.64 & & 0.14 & $(0.33)$ & $(1.89)$ & $\mathrm{S} / \mathrm{U}$ & $(0.86)$ \\
\hline Halal beverages & & $(-1.8)^{* *}$ & & & & & & \\
\hline TB with the UK in & 2.27 & -1.5 & & 0.68 & $(0.56)$ & $(0.44)$ & $\mathrm{S} / \mathrm{S}$ & $(0.23)$ \\
\hline Halal beverages & $(1.2)$ & $(-1.0)$ & & & & & & \\
\hline TB with the China in & 17.46 & -3.22 & -8.96 & 0.56 & $(1.04)$ & $(0.71)$ & $\mathrm{S} / \mathrm{S}$ & $(3.28)$ \\
\hline Halal beverages & $(2.1)^{* *}$ & $(-0.4)$ & $(-1.4)$ & & & & & \\
\hline TB with Singapore in & -2.38 & 1.02 & -4.53 & 0.83 & $(0.51)$ & $(0.16)$ & $\mathrm{S} / \mathrm{S}$ & $(1.48)$ \\
\hline non-Halal beverages & $(-1.8)$ & $(0.6)$ & $(-2.7)^{* *}$ & & & & & \\
\hline TB with Japan in & & 2.06 & 3.39 & 0.66 & $(0.81)$ & $(1.82)$ & $\mathrm{S} / \mathrm{S}$ & $(1.95)$ \\
\hline non-Halal beverages & & $(1.5)$ & $(2.3)^{*}$ & & & & & \\
\hline TB with the US in & 4.99 & -10.83 & & 0.46 & $(0.37)$ & $(0.67)$ & $\mathrm{S} / \mathrm{S}$ & $(0.38)$ \\
\hline non-Halal beverages & (1.1) & $(-2.2)^{*}$ & & & & & & \\
\hline TB with the UK in & -2.56 & 2.3 & & 0.50 & $(0.01)$ & $(2.73)$ & $\mathrm{S} / \mathrm{S}$ & $(0.77)$ \\
\hline non-Halal beverages & $(-1.2)$ & $(1.1)$ & & & & & & \\
\hline TB with the China in & & 12.27 & & 0.26 & $(22.11)^{*}$ & $(2.25)$ & $\mathrm{S} / \mathrm{S}$ & $(4.25)^{*}$ \\
\hline non-Halal beverages & & $(2.2)^{*}$ & & & & & & \\
\hline
\end{tabular}

* indicates significance at $5 \%$ level, $* *$ indicates significance at $10 \%,{ }^{a}$ numbers inside parentheses are t-ratios

${ }^{b}$ numbers inside parentheses are F-Statistics.

The traditional definition of the J-Curve suggests quick trade balance worsening followed by an improvement over later periods when REX depreciation takes place (Bahmani-Oskooee \& Ratha, 2004). This can be captured by looking at the signs of $\Delta \operatorname{LnREX}_{t}, \Delta \operatorname{LnREX}_{t-1}$, and $\Delta \operatorname{LnREX}_{t-2}$. A pattern of positive significant coefficient followed by a negative significant coefficient indicates the existence of the J-Curve phenomena. Thus, from the ten regression results provided above, we find no sequence of any significant first differenced REX, which leads us to conclude, without assessing the sign, the J-Curve phenomena does not appear. 
However, REX seems to have a short-run effect on TB in eight cases out of 10. In five cases out of the eight significant ones, depreciation in the real exchange rate has the expected short-run worsening effect on trade balance.

Concerning the diagnostic tests, little support can be found for misspecification, heteroscedasticity, autocorrelation, and regression instability. Furthermore, the average $\mathrm{R}^{2}$ for all 10 regressions equals 0.52 .

4.3 The Long-Run Coefficient Estimates

Table 3. Coefficient estimates for the long-run effects

\begin{tabular}{lcccc}
\hline \multicolumn{1}{c}{ Data description } & \multicolumn{4}{c}{ Long-run estimates ${ }^{\text {a }}$} \\
Description & $\ln Y_{m a}$ & $\ln Y_{x}$ & $\ln R E X$ & C \\
\hline TB with Singapore in Halal beverages & 9.95 & -4.41 & -7.74 & -9.46 \\
& $(0.77)$ & $(-0.42)$ & $(-0.76)$ & $(-1.64)$ \\
TB with Japan in Halal beverages & -7.23 & 69.65 & 1.89 & -121.84 \\
& $(-0.31)$ & $(0.47)$ & $(0.11)$ & $(-0.52)$ \\
TB with the US in Halal beverages & -13.42 & 22.07 & -12.32 & -11.46 \\
& $(-0.98)$ & $(0.76)$ & $(-1.30)$ & $(-0.43)$ \\
TB with the UK in Halal beverages & -5.41 & 17.67 & -4.10 & -21.47 \\
& $(-2.21)^{*}$ & $(3.10)^{*}$ & $(-2.40)^{*}$ & $(-3.83)^{*}$ \\
TB with the China in Halal beverages & 6.60 & -7.88 & 4.21 & 4.37 \\
TB with Singapore in non-Halal beverages & $(0.87)$ & $(-1.95)^{* *}$ & $(2.01)^{* *}$ & $(0.60)$ \\
& -128.31 & 95.05 & -9.21 & 75.77 \\
TB with Japan in non-Halal beverages & $(-0.14)$ & $(0.14)$ & $(-0.14)$ & $(0.14)$ \\
& 3.87 & -18.60 & 0.81 & 30.30 \\
TB with the US in non-Halal beverages & $(1.21)$ & $(-1.13)$ & $(0.30)$ & $(1.10)$ \\
& -22.28 & 58.57 & -23.58 & -57.82 \\
TB with the UK in non-Halal beverages & $(-1.09)$ & $(1.14)$ & $(-1.30)$ & $(-1.11)$ \\
TB with the China in non-Halal beverages & -3.64 & 11.21 & -4.00 & -10.05 \\
& $(-0.56)$ & $(0.81)$ & $(-1.17)$ & $(-0.80)$ \\
& -49.16 & 21.31 & 23.58 & 61.25 \\
& $(-1.71)$ & $(1.52)$ & $(1.72)$ & $(1.97)^{* *}$ \\
\hline
\end{tabular}

* indicates significance at $5 \%$ level, $* *$ indicates significance at $10 \%,{ }^{a}$ numbers inside parentheses are t-ratios

As argued by Rose and Yellen (1989), the J-Curve can also be defined as the long-term improvement of the trade balance after a depreciation in the real exchange rate (Bahmani-Oskooee \& Brooks, 1999). Thus, regardless the sign of the short-run coefficients of REX, a significant and negative coefficient in the long-run can place enough evidence for the J-Curve.

Following the modern definition of the J-Curve, we find support for the J-Curve in one sector only. However, no significant effect of any of the explanatory variables on TB in the long-run can be supported in any of the non-Halal beverages sectors, supporting that Malaysia's trade in non-Halal sectors is driven by other factors.

\section{Conclusion}

In this paper, we tried to investigate the effect of real exchange rate movements on Malaysia's bilateral sectoral trade balance of Halal and non-Halal beverages with five of its largest trading partners using the dynamic theory of the J-Curve.

Following the classical definition of the J-Curve, no support could be placed for the phenomena, while following the modern definition shows support for the case of Malaysia's trade with the UK in Halal beverages. However, 
REX has a short-run effect on TB in eight cases out of 10. In five of them, depreciation in the real exchange rate has the expected short-run worsening effect on trade balance.

Most interestingly, in the long-run, none of the explanatory variables seems to have any significant effect on Malaysia's trade in non-Halal beverages, which suggests that Malaysia's skyrocketing trade in non-Halal beverages is uncompetitive and not driven by the level of GDP of neither itself, nor any of its trading partners.

\section{References}

Al-Qardawi, Y. (1997). The lawful and the prohibited in Islam. Islamic Books.

Al Jallad, N. (2008). The concepts of al-halal and al-haram in the Arab-Muslim culture: A translational and lexicographical study. Language Design: Journal of Theoretical and Experimental Linguistics, (10), 77-86.

Anju, G. -K., \& Uma, R. (1999). Is there a J-curve? A new estimation for Japan. International Economic Journal, 13(4), 71-79. http://dx.doi.org/10.1080/10168739900000045

Auboin, M., \& Ruta, M. (2013). The relationship between exchange rates and international trade: A literature review. World Trade Review, 12(3), 577-605. http://dx.doi.org/10.1017/S1474745613000025

Baalbaki, R., \& Ba'albaki, M. (1999). al-Mawrid. Dar El-ilm Lilmalayin.

Bahmani-Oskooee, M., \& Brooks, T. J. (1999). Bilateral J-curve between US and her trading partners. Review of World Economics, 135(1), 156-165.

Bahmani-Oskooee, M., \& Ratha, A. (2004). The J-curve dynamics of US bilateral trade. Journal of Economics and Finance, 28(1), 32-38. http://dx.doi.org/10.1007/BF02761452

Bahmani-Oskooee, M., \& Wang, Y. (2008). The J-curve: Evidence from commodity trade between US and China. Applied Economics, 40(21), 2735-2747. http://dx.doi.org/10.1080/00036840600970328

Clarke, A., \& Kulkarni, K. G. (2010). Testing the Application of Heckscher-Ohlin Theorem to Contemporary Trade Between Malaysia and Singapore. Journal of Emerging Knowledge on Emerging Markets, 1(1), 10. http://dx.doi.org/10.7885/1946-651X.1009

Henderson, J. C. (2003). Managing tourism and Islam in peninsular Malaysia. Tourism Management, 24(4), 447-456. http://dx.doi.org/10.1016/S0261-5177(02)00106-1

Hendry, D. F., \& Mizon, G. E. (1990). Evaluating dynamic econometric models by encompassing the VAR.

Jernigan, D. H., \& Indran, S. (1997). Alcohol use patterns, problems and policies in Malaysia. Drug and alcohol review, 16(4), 401-409. http://dx.doi.org/10.1080/09595239700186801

Junz, H. B., \& Rhomberg, R. R. (1973). Price competitiveness in export trade among industrial countries.

Kortteinen, T. (1999). Alcohol in Malaysia: The impact of social transformation. Contemp. Drug Probs., 26, 391.

Kremers, J. J., Ericsson, N. R., \& Dolado, J. J. (1992). The power of cointegration tests. Oxford bulletin of economics and statistics, 54(3), 325-348. http://dx.doi.org/10.1111/j.1468-0084.1992.tb00005.x

Krueger, A. O. (1983). The Factor Proportions Explanation of Trade, Distortions, and Employment. Trade and Employment in Developing Countries, 3: Synthesis and Conclusions (pp. 55-85). University of Chicago Press.

Magee, S. P. (1973). Currency contracts, pass-through, and devaluation. Brookings Papers on Economic Activity, 303-325. http://dx.doi.org/10.2307/2534091

Michalak, L., \& Trocki, K. (2006). Alcohol and Islam: An overview. Contemp. Drug Probs., 33, 523.

Narayan, P. K. (2005). The saving and investment nexus for China: Evidence from cointegration tests. Applied Economics, 37(17), 1979-1990. http://dx.doi.org/10.1080/00036840500278103

Nasr, S. V. R. (2005). The Rise of "Muslim Democracy". Journal of Democracy, 16(2), 13-27. http://dx.doi.org/10.1353/jod.2005.0032

Ngow, H. A., Wan Khairina, W., Teh, L., Lee, W., Harun, R., Ismail, R., \& Salleh, M. (2009). CYP2C9 polymorphism: Prevalence in healthy and warfarin-treated Malay and Chinese in Malaysia. Singapore medical journal, 50(5), 490.

Pesaran, M. H., Shin, Y., \& Smith, R. J. (2001). Bounds testing approaches to the analysis of level relationships. Journal of applied econometrics, 16(3), 289-326. http://dx.doi.org/10.1002/jae.616

Rashid, M. Z. A., \& Ho, J. A. (2003). Perceptions of business ethics in a multicultural community: The case of 
Malaysia. Journal of Business Ethics, 43(1-2), 75-87. http://dx.doi.org/10.1023/A:1022963232042

Regenstein, J., Chaudry, M., \& Regenstein, C. (2003). The kosher and halal food laws. Comprehensive Reviews in Food Science and Food Safety, 2(3), 111-127. http://dx.doi.org/10.1111/j.1541-4337.2003.tb00018.x

Rose, A. K., \& Yellen, J. L. (1989). Is there a J-curve? Journal of Monetary Economics, 24(1), 53-68. http://dx.doi.org/10.1016/0304-3932(89)90016-0

Russell, R. V. (2003). Tourists and refugees: Coinciding sociocultural impacts. Annals of Tourism Research, 30(4), 833-846. http://dx.doi.org/10.1016/S0160-7383(03)00062-8

Sabry, W. M., \& Vohra, A. (2013). Role of Islam in the management of Psychiatric disorders. Indian journal of psychiatry, 55(Suppl 2), S205. http://dx.doi.org/10.4103/0019-5545.105534

Tan, A. K., Yen, S. T., \& Nayga Jr, R. M. (2009). Factors affecting alcohol purchase decisions and expenditures: A sample selection analysis by ethnicity in Malaysia. Journal of family and economic issues, 30(2), 149-159. http://dx.doi.org/10.1007/s10834-009-9148-9

Wan Hassan, W. M., \& Awang, K. W. (2009). Halal food in New Zealand restaurants: an exploratory study. International Journal of Economics and Management, 3(2), 385-402.

\section{Appendix}

\subsubsection{Data definitions and sources}

All the data used in this study come from the following sources:

a. World Bank.

b. International Financial Statistics of IMF-IFS (CD-ROM).

c. World Trade Integrated Solution (WITS) World Bank.

\section{Variables Definitions}

$\mathrm{TBi}=$ Impi/Expi Malaysia's imports of commodity $\mathrm{i}$ from country $\mathrm{x}$ divided by its exports to country $\mathrm{x}$ of the same commodity.

Yma= A measure of US's real income, proxied in real Gross Domestic Product (2005=100). The data come from source a.

$Y x=A$ measure of $x$ 's real income, proxied in real Gross Domestic Product $(2005=100)$. The data come from source a.

Nexj: Nominal bilateral exchange rate (period average) defined as number of Malaysian ringgits to purchase one unit of currency of country $x$. Data come from source $b$.

$\mathrm{Pma}=$ Malaysia's price level proxied by the consumer price index $(2005=100)$. Data come from source $b$.

$\mathrm{Px}=$ Country $\mathrm{x}$ 's price level proxied by the consumer price index $(2005=100)$. Data come from source $\mathrm{b}$.

$$
R E X=\frac{P_{m a} * N E X_{i}}{P_{x}}
$$

\section{Copyrights}

Copyright for this article is retained by the author(s), with first publication rights granted to the journal.

This is an open-access article distributed under the terms and conditions of the Creative Commons Attribution license (http://creativecommons.org/licenses/by/3.0/). 